\title{
Trade, Technology and Real Wages in the United States: A Modern and Historical Perspective
}

\author{
Ravi Batra ${ }^{\mathrm{a}^{*}}$ and Hamid Beladi ${ }^{\mathrm{b}}$ \\ ${ }^{a}$ Southern Methodist University \\ ${ }^{b}$ University of Texas at San Antonio
}

\begin{abstract}
In this paper we re-examine the contentious facts and issues and argue that the technology explanation of the entire real-wage controversy contradicts logic, common sense and history, whereas the trade explanation passes the severe test of rationality. Using a simple model we illustrate that in an open economy technical improvements may generate a fall in some or all types of real earnings, but not in a closed economy.
\end{abstract}

JEL Classification: F10, O33, J31

Keywords: Real wages; trade liberalization; technological change

\section{Introduction}

One of the more contentious issues in recent economic thought is the behaviour, or misbehaviour, of real wages in the United States. Since the early 1970s, contrary to what is expected in a growing and increasingly globalized economy, real earnings have not only become more and more unequal among a variety of workers but have also suffered a nearly relentless decline for a large section of the population. On this point, there is now a rare, though belated, consensus among the economists. What is still hotly debated is the primary source of the soaring inequality in real wages. Some blame it on the increasing openness or trade liberalization of the American economy. Others, and most economists, blame it on the nature of technological change in recent years. ${ }^{1}$

* Contact author: Ravi Batra, Department of Economics, Southern Methodist University, Dallas, TX 75275 , USA. Tel: (214)768-2707. Email: rbatra@smu.edu.

${ }^{1}$ For a perspective of the two viewpoints including openness and technological change, see William Cline (1997), Wood (1995) and Levy and Murnane (1992). Feenstra and Hansen (2001) also offer a large bibliography on the subject. Someone may argue that as the real wages fell, profits rose sharply, which in turn caused a big rise in share prices, thus eventually benefiting the workers who bought stocks. This argument could have been valid if the share markets had not crashed from 2000 to 2002. 
In this paper we re-examine the contentious facts and issues and argue that the technology explanation of the entire real-wage controversy contradicts logic, common sense and history, whereas the trade explanation passes the severe test of rationality. This way we theoretically support the empirical results derived by Feenstra and Hansen (2001) and Feenstra (2003).

\section{Some Stylized Facts}

Let us begin with some stylized facts, which were in dispute for many years, but which Peter Gottschalk (1997) re-explored in a recent paper, and arrived at the following conclusions that are now agreeable to most:

1. "During the 1950 s and 1960 s, mean wages in the United States grew rapidly, and the dispersion around this growing mean changed very little. Starting in the 1970s and continuing into the 1980s and 1990s, these patterns were reversed: mean wages grew very slowly, and inequality increased rapidly."

2. "For both men and women, real wages were increasing steadily during the 1960s and into the early 1970s.... But after 1973, the pattern of male and female wages diverges. Men's wages leveled off; the average real weekly wage for a male worker in 1994 was actually lower than was the average in $1973 \ldots$ In sharp contrast to the near constancy of mean wages for males since 1973, real wages for women grew at 2.7 percent per year from 1973 to 1993."

3. "The increase in inequality reflects an absolute as well as a relative decline in the earnings of less skilled workers. In fact the decline in wages for less skilled workers cancelled out the impact of the rising wages for more skilled workers, so little or no change in mean wages occurred."

Figure 1: The Real Wage and Productivity Indexes in the United States: 1950-1973

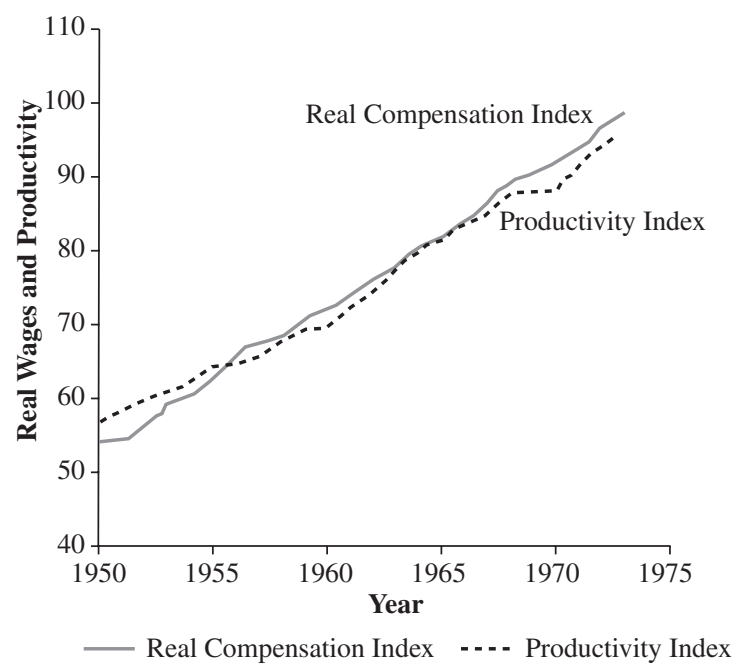


Figure 2: The Real Wage and Productivity Indexes in the United States: 1973-1997

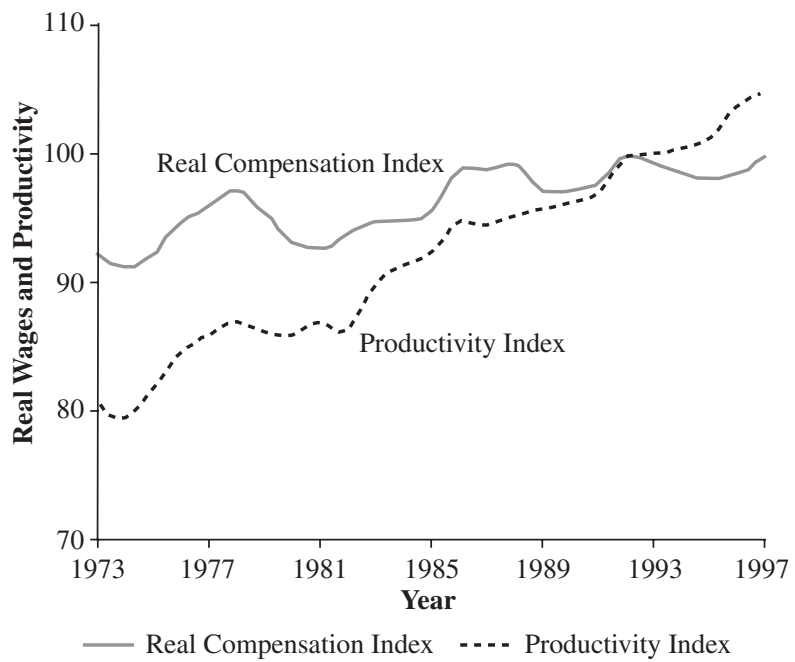

Source: The Economic Report of the President (1999), p 384.

4. Another notable and indisputable feature of recent US economy is the sharp growth of employment in the service sector comprising a wide variety of service industries coupled with a large decline in manufacturing workforce. Some economists approach the inequality question from the viewpoint of real wages in manufacturing versus services, with service wages at two-thirds of wages in manufacturing. In this view manufacturing real wages have been more or less constant, whereas services wages are not only lower but also have been declining since 1973, although a small fraction of the service sector, notably finance, pays some of the highest wages. (Batra, 1992 and Thurow, 1992).

Figures 1 and 2 neatly capture the ethos of Gottschalk's remarks. Both graphs draw on the data provided by The Economic Report of the President and rely on the same definitions of real wages and labour productivity. Thus the real wage, depicted by the heavy-set line, is measured by the real compensation index that includes hourly wages and benefits in the non-farm sector, whereas the productivity measure, displayed by the dashed line, is given by an index of hourly output in the same sector. However, this is where the similarities end. The contrast between the messages of the two graphs is rather striking. In Figure 1 , the real wage index closely parallels the productivity index, with both soaring between 1950 and 1973, whereas in Figure 2, the real-wage index remains more or less constant between 1973 and 1997, while the productivity index continues to rise, although at a somewhat slower pace than before. Even though earnings rose slightly between 1973 and 1997, there were some shorter periods during which they either stagnated or fell, as, for instance, between 1978 and 1981, and then again between 1991 and 1996.

Incidentally, it is worth pointing out that the rest of US economic history, as far back as the data go, mirrors the message of Figure 1, namely real wages in America went up for 
both men and women, and for workers at all levels and sectors, all through American annals - except after 1973 (Batra, 1993, 35-53). For instance, between 1874 and 1950, the average real wage more than tripled, and the real wages of the unskilled also jumped sharply, partly as a result of the introduction of the minimum wage in 1938.

\section{The Technology Explanation}

Let us restate two of the three trends noted above. First, the overall real wage has either remained constant or grown at a snail's pace since 1973, and second, the real wage of the unskilled workers has actually declined. A variety of reasons may account for these changes, but as Abel and Bernanke (1995) note: "The explanations offered by most economists for both these trends focus on the pattern of technological change".

Let us begin with the inequality issue. The technology explanation of this issue is that since the early 1970s new technology, especially that involving the use of computers, has increased the demand for skilled labour at the expense of unskilled labour. "For example," write Abel and Bernanke (1995), "some new manufacturing techniques rely considerably more on worker initiative and problem solving than did the traditional assembly-line approach and thus require better-skilled workers. Computerization is another development that has in many cases increased the productivity of more skilled workers while squeezing out those without the education or training to use the new tool effectively." This phenomenon is known as the skill-biased technical change, of which the best-known exponent is a widely cited paper by John Bound and George Johnson (1992). ${ }^{2}$

Abel and Bernanke explain the Bound-Johnson thesis in terms of two graphs, presented here as Figures 3 and 4. The first is a demand-supply graph for the market for skilled labour, and the second is the corresponding graph for unskilled labour. In both figures, $\mathrm{D}_{1}$ and $\mathrm{S}_{\mathrm{L}}$ are the pre-technical change labour demand and supply curves, and $\mathrm{D}_{2}$ is the labour demand curve after the skill-biased technical change, which raises the marginal product, and hence the demand, for skilled labour and lowers the marginal product, and hence the demand, for the unskilled worker. As a result, the equilibrium point shifts from $\mathrm{E}$ to $\mathrm{F}$, but the real wage rises for the skilled worker in Figure 3 from $\mathrm{W}_{1}$ to $\mathrm{W}_{2}$, and falls for the less skilled counterpart in Figure 4.

\footnotetext{
${ }^{2}$ Almost everyone believing in the technology explanation refers to this paper. Cline regards this paper to be an important contributor to the technology explanation, which is now cited even by non-economists. Kirk Kennedy (1996), a prominent attorney, cites the technology explanation in his review of Batra's "Myth of Free Trade".
} 
Figure 3: Market for Skilled Labour

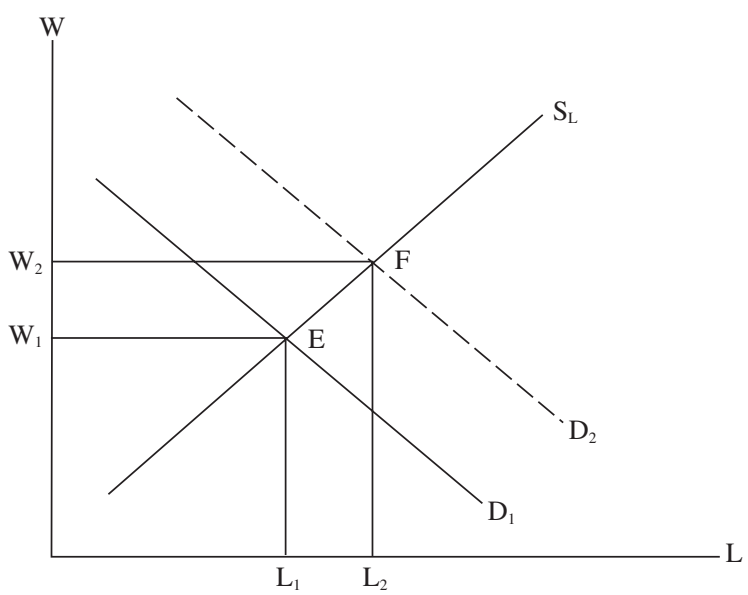

Figure 4: Market for Unskilled Labour

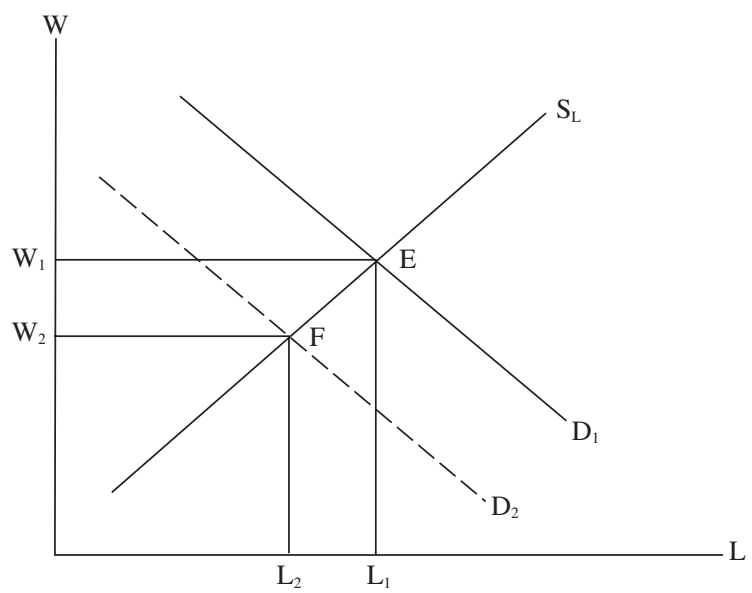

This is then a simple explanation for the observed rise in the wage inequality, and is supported econometrically by Bound and Johnson, using the data from 1973 to 1988. There are, however, a few logical problems with this approach. First, it contradicts the observed fact that real wages also fell for skilled workers between 1973 and 1988. Take a look at Table 1 , which is carved out of figures provided by Bound and Johnson themselves. The table reveals that for men real wages dropped at all levels of education and experience, whereas for women real wages tumbled in most cases. In all, those with lower education suffered much more than those with a higher level of education, so that the relative wage between the skilled and the unskilled fell sharply. To be sure, benefits are not included in these estimates but, as Bound and Johnson note, benefits fail to reverse their findings. 
Even though real wages for the skilled also fell in their study, Bound and Johnson went on to conclude that the primary cause of the relative wage decline of those with low education was "skilled-labor-biased technical change". Most of those who accept the Bound-Johnson thesis take what they like in this study and ignore the great contradiction. Abel and Bernanke, among others, while expanding on the technology explanation for the rise in inequality, reject the Bound-Johnson finding that skilled worker earnings have declined. This procedure may be appropriate in incorporating ideas from theoretical papers but not from empirical estimates, which usually stand and fall together.

Table 1

Bound-Johnson Estimates of Average Real Hourly Wage Rates (In 1988 Dollars)

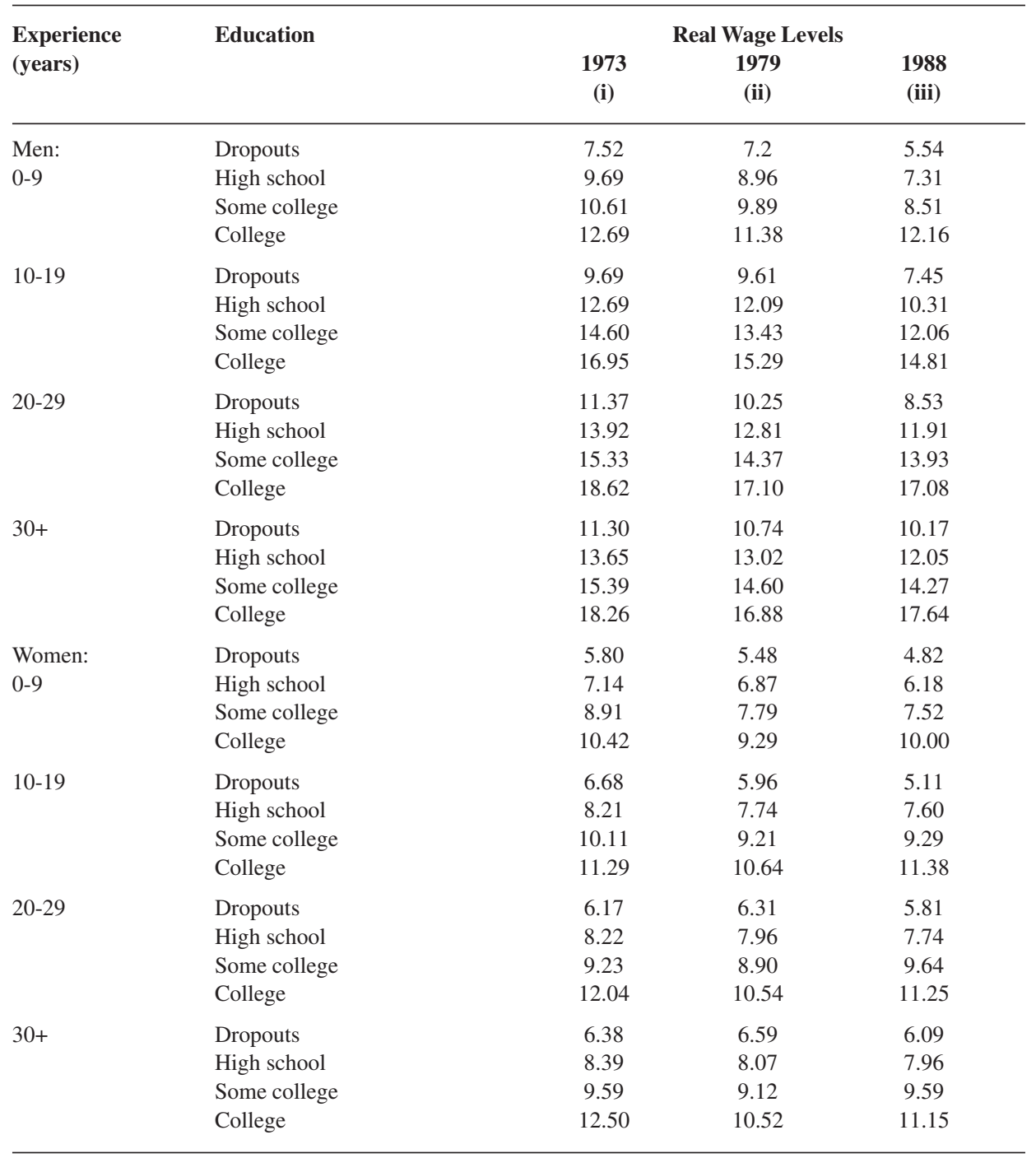

Source: Bound and Johnson, AER, 1992, Table 1. 
This is just one example of the logical contradictions permeating this literature. If the primary cause of the rise in earnings inequality were the skill-biased technical change, then the real wages of the skilled would have risen not just relatively but also absolutely. But that did not happen, at least according to the Bound-Johnson study, which in reality argues that both skilled and unskilled real wages fell because of the skill-biased technical change. Such a conclusion challenges one's common sense.

Other contradictions in this approach are also noteworthy. It is well documented and accepted that female wages rose faster than male wages after 1973. Even if skilled male wages did not fall, as some argue, their growth certainly lagged behind the earnings growth for women. According to the technical change explanation then, women benefited more from computers than men. Stated another way, this argument implies that, given the labour supply curves, the use of computers raised the demand for female labour faster than that for male labour. Why should this be the case? There is no a priori reason to believe that the demand for female computer experts outpaced the demand for male experts.

The Bound-Johnson thesis is a contradiction of history as well. Skill-biased technical change is not a new phenomenon. For over two centuries the United States has enjoyed the variegated fruit of improving technology, which, without exception, has been labour saving. The technology explanation suggests that computerization economizes on the use of unskilled labour, i.e. less unskilled workforce is then in demand. However, all through American history, technical progress has been labour-saving in the sense that the same amount of output can be produced by less labour (Fite and Reese, 1973). New technology has also economized on the use of manual or unskilled labour. Citing Seymour Bell, Fite and Reese remark that in 1900 "visitors to American factories were impressed by the way 'in which machinery is used and all sorts of devices are employed in order to save manual labor'." But real wages rarely fell for the skilled as well as the unskilled prior to 1973. Even during the Great Depression of the 1930s, real wages grew by the end of the decade (Robert Gordon, 1998). As Lester Thurow remarks: "The hallmark of the industrial revolution has been the slow replacement of the unskilled by the skilled. But for most of its duration, public investments in education have raised the supply of skills at least as fast, and perhaps faster, than the market demanded" (1996).

Two points are noteworthy here. First the skilled-labour-biased technical change goes hand in hand with industrial revolution, as skilled work tends to supersede unskilled work. But American industrial revolution began in the early nineteenth century, and is far from a new phenomenon. American innovations of the past, such as the railroads, assembly lines, and the automobile among numerous others, were just as monumental, if not more so, than the modern-day computers. They caused big falls in the demand for unskilled workers of those days. Yet real wages continued to rise for both the skilled and the unskilled.

Even if you argue that computers may have hastened the replacement of unskilled work, a questionable notion, then this is just an incremental increase in a phenomenon extending over two centuries. An incremental change cannot cause as giant a metamorphosis as the reversal of more than a century-long real wage rise. The post-1973 wage slowdown or fall in the wake of rising national productivity is a totally new phenomenon, which suggests that something must have occurred that had never happened in the US chronicle before.

The second point raised by Thurow's quote is that the supply of educated labour has risen just as fast as the demand for skilled or educated labour, so that technical change itself should not raise the skill premium observed since the early 1970 s. 
Thurow's analysis includes both cases of wage inequality noted above, namely the rising disparity between the wages of the educated and the uneducated, and the rising disparity between earnings in services and manufacturing. Technology plays a part in the case of intersectoral wage differences as well, namely technical progress in manufacturing outpaces that in services, although some service industries have indeed enjoyed a fast pace of technical advance (Williamson, 1991). However, here again the same difficulty arises, namely the fact that manufacturing technical advances have always been ahead of advances in the rest of the economy. But real wages did not fall in either sector prior to 1973. What we need to explain is not just a fall in the real earnings of some or all sections of society, but a fall in earnings in the background of a continued rise in national productivity. If wages fall when national productivity goes down, it is understandable; but when they drop in spite of the productivity rise, as after 1973, that is something strange and means that a complex array of factors must be at work in generating the paradox.

\section{Resource Allocation}

Consistency and logic demand that our theory should explain the real wage trends all through American history. The key to understanding the earnings behaviour is the allocation of resources among the major sectors in any economy. The main sectors in the nineteenth century were agriculture and services, while manufacturing began its rise during the 1810s, when tariffs went up sharply. Today, and since 1900, the two main sectors are manufacturing and services.

Throughout US history technical change has been much stronger in manufacturing than in other sectors (Thurow, 1992). Manufacturing $(M)$ thus has been a dynamo that charges the rest of the economy. Let us then divide the economy into two major sectors, $M$ and $S$, where sector $M$ experiences faster technical improvements than sector $S$, which represents a combination of farming and services. Let us also assume that labour is the only mobile factor in perfectly competitive markets, whereas other factors such as capital and land are specific to each sector. Land is not an important factor today, but it was the main source of GDP until the end of the nineteenth century. In this setting, labour allocation and real wages are determined by the following simple equation:

$$
\text { PmMPLm }=\theta \text { PsMPLs, } \theta \geq 1
$$

Here $M P L$ is the marginal product of labour in any sector, $P_{i}$ is the price in the $i$ th sector and $\ddot{E}$ is the intersectoral wage differential initially equal to one. Define $p=P m / P s$ as the relative price of $M$ with respect to $S$. Then the resource allocation equation implies that

$$
p M P L m=\theta M P L s
$$

This equation is the key to comprehending the resource allocation, which in our model is governed by the sectoral-price ratio as well as anything that affects the marginal productivities of labour, which in turn are determined by capital, physical and human, and the state of technology. In both sectors some workers are skilled and some unskilled, and 
we assume that unskilled labour can be expressed as a certain equivalent of the skilled work. For instance, a skilled worker, offering the same number of hours, may produce twice as much as an unskilled worker, and so on. This way total work effort in both sectors can be represented by the number of hours spent by employees on the job.

Let us start with the case where wages are equal in both sectors, so that in equilibrium the marginal value product of labour is the same everywhere. This case is presented in the well-known specific-factor diagram popularized by Jones (1971). In Figure 5, LDM (or pMPLm) is the labour demand curve for sector $M$ and LDS (MPLs) is the corresponding curve for sector $S$. The vertical axis represents the service real wage, which is defined as money wage $(M W)$ divided by $P s$, and the horizontal axis represents labour, which is assumed to be fully employed. Equilibrium occurs at point $\mathrm{E}$, which sets labour allocation at $\mathrm{A}$ and the $M W / P s$ at B. Now suppose technical progress occurs in manufacturing alone, raising the marginal product of capital and at least skilled labour. Then at constant $p$ the labour demand curve shifts up to RS, equilibrium shifts to $\mathrm{G}$ and labour allocation to $\mathrm{H}$. Thus labour moves from $S$ to $M$.

However, $p$ will not stay constant whether a large US economy is closed or open. In fact, the relative price of manufacturing or $p$ will fall in the new equilibrium because of an excess supply in $M$ at the old $p$. This will tend to mitigate the rightward shift of the labour demand curve in $M$, so that the final labour allocation point will lie to the left of $\mathrm{H}$ (not shown). Could $p$ fall so much as to actually lower the labour employment in $M$ ? Yes, indeed. If the economy is closed, then an inelastic demand for manufactures could cause a great fall in $p$, enough to lower the marginal value product in $M$. But since manufacturing price elasticity of demand generally exceeds one, and has done so all through US history, this theoretical possibility is ruled out under autarky (Batra, 1992).

\section{Figure 5: Resource Allocation in the Economy}

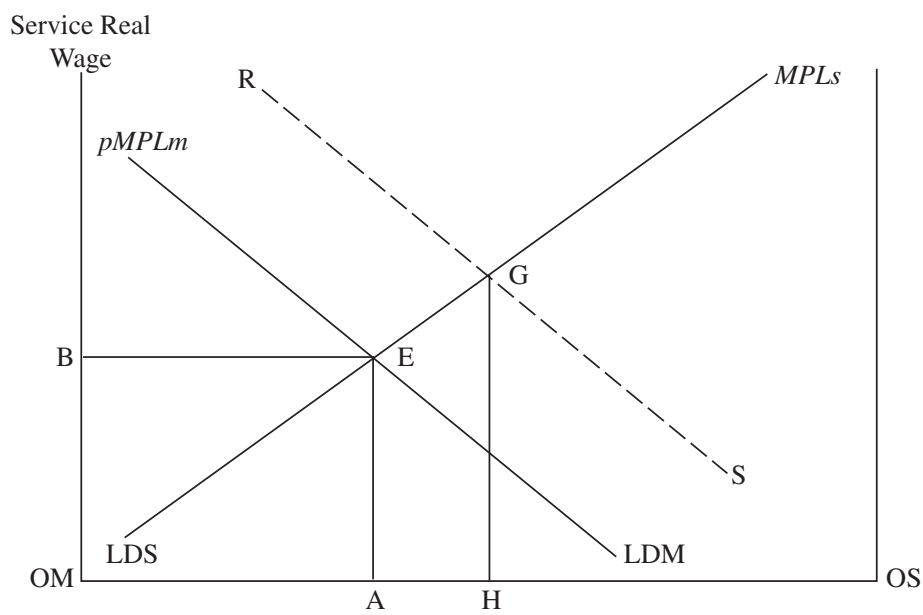

In an open economy, $p$ is determined by foreign and domestic elasticities of import demand. Here $p$ could fall even if $M$ 's price elasticity of demand exceeds one, if foreign import demand is inelastic (Batra, 1992). $p$ could also fall sharply if under increasing 
globalization the US technical advance leads to an advance in foreign countries either simultaneously or with a slight lag, even if foreign import demand is elastic.

The upshot of this line of reasoning is that in a closed economy technical progress in $M$ alone cannot cause a fall in labour employment in manufacturing, but in an open economy it can, because then $p$ may decline sharply. So far we have allowed the technical advance to occur only in $M$, but the argument changes little if both sectors experience the advance so long as the rate of technical progress in manufacturing exceeds that in the other sector. Henceforward we will call $M$ the progressive sector relative to sector $S$ to reflect that technological improvements occur in all areas of the economy.

If wages are not the same in the two sectors, then the analysis remains essentially unchanged, but its expression is somewhat different. ${ }^{3}$ This is displayed in Figures 6 and 7. As before, the service real wage is measured along the vertical axis and labour employment along the horizontal axis. In $M$ the labour demand curve is again given by $p M P L m$, and that in $S$ by MPLs. But we now have labour supply curves in each sector as well, given by LSM and LSS. The equilibrium service real wage in both sectors is at B, but the two wages are not the same.

Now let technology improve only in $M$, so that its labour demand curve, with $p$ being constant, shifts up to RS. Employment in $M$ rises from A to $\mathrm{H}$, and so does its real wage defined in any way. This induces a labour movement from $S$ to $M$. Thus, with full employment, the labour supply curve in $S$ shifts to the left to GM, in proportion to the rise of employment in $M$, so that in the new equilibrium employment in $S$ falls from $\mathrm{H}$ to $\mathrm{A}$, and by the same amount as the rise in $M$ employment. If $p$ falls in the new equilibrium, the labour demand curve tends to move back from RS, and it may even move below LDM, in which case labour movements are reversed. Thus the fact that wages are different in the two sectors does not alter the analysis of resource allocation in any way. But, as shown later, it will make a difference in the analysis of changes in real wages.

\section{Figure 6: Labour Market in Manufacturing}

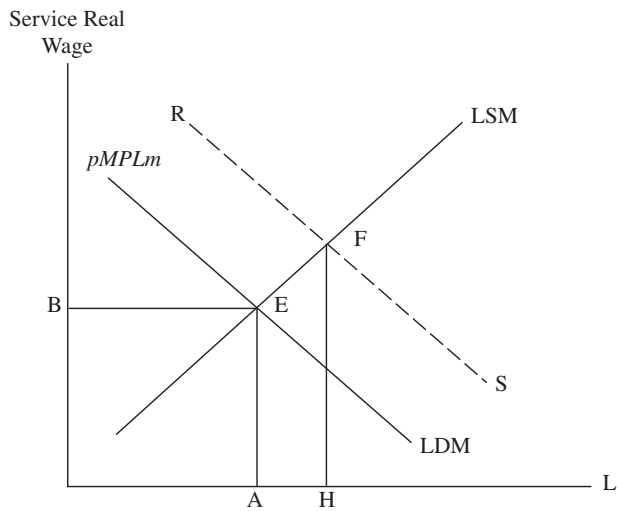

\section{Figure 7: Labour Market in Services}

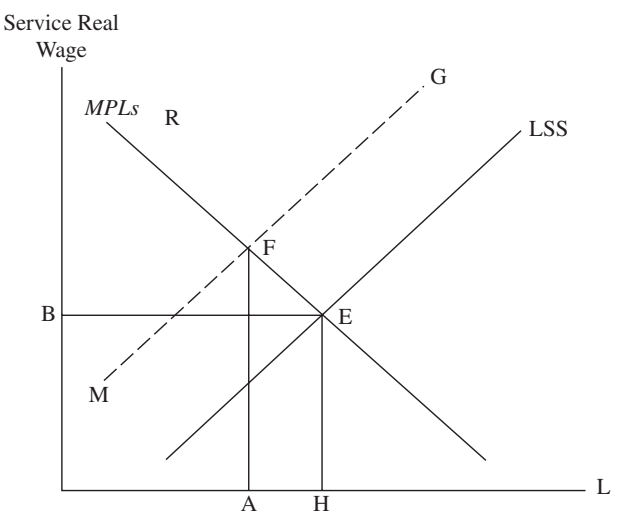

\footnotetext{
${ }^{3}$ Here we enter the realm of the trade literature dealing with inter-industry wage differentials. For more on this, see Batra (1973).
} 
Let us now apply this argument to American history. At the dawn of the Constitution in 1789, the young republic of the United States was predominantly an agrarian society, with 70 percent of its labour force employed in farming, about 25 percent in services and less than 5 percent in manufacturing. The economy was more or less closed either because of large tariffs or because of high transportation costs. Both imports and exports were extremely small. Starting with the second decade of the nineteenth century, manufacturing productivity and its labour demand curve began to shift outwards, triggering an almost relentless process of labour migration from agriculture to manufacturing. Technology also improved in farming but not at the same pace as in $M$. Industrial prices, of course, fell, both relatively and absolutely, but not enough to reverse the labour movements into the progressive sector

By the end of the nineteenth century, manufacturing employed about a third of the labour force, whereas the employment share of agriculture was down to 40 percent, with the rest going to services. During the twentieth century, agricultural share continued to go down, but service share went up while the manufacturing share held steady. By 1965 the service employment stood at about 60 percent, manufacturing at 30 percent, and farming at less than 10 percent. Thus between 1900 and 1965 the manufacturing share of employment had remained more or less constant. All through this period, the United States was essentially a closed economy, with imports and exports each at less than 5 percent of GDP, and with total trade at less than 10 percent of GDP (Salvatore, 1998). And throughout this long period real wages for all sections jumped with rising national productivity.

Following 1965 the economy began to open up to imports, at first slowly, and then in a flood. By 1973, a year after the completion of the Kennedy-round of tariff cuts, the trade to GDP ratio exceeded 12 percent, and began a steady climb that has yet to peak. It is after 1973, and especially after 1975, that manufacturing employment share began its sharp and steady fall. Since technology continued to improve faster in manufacturing than in other sectors, the fall in $M$ 's share of the workforce can only be explained by a sharper fall in the terms of trade between $M$ and $S$. Did this happen? Indeed it did.

The industrial price ratio can be computed by dividing the consumer price index of all commodities (CPIC) with the consumer price index of all services (CPIS). This is done in Table 2 . 
Table 2

The Price Ratio between Manufacturing and Services in Selected Years: 1950-1997

\begin{tabular}{lccc}
\hline Year & CPIC $^{*}$ & CPIS $^{* *}$ & CPIC/CPIS \\
\hline 1950 & 29.0 & 16.9 & 1.72 \\
1955 & 31.3 & 20.4 & 1.53 \\
1960 & 33.6 & 24.1 & 1.39 \\
1965 & 35.2 & 26.6 & 1.32 \\
1970 & 41.7 & 35.0 & 1.19 \\
1975 & 58.2 & 48.0 & 1.21 \\
1980 & 86.0 & 77.9 & 1.10 \\
1985 & 105.4 & 109.9 & 0.96 \\
1990 & 122.8 & 139.2 & 0.88 \\
1995 & 136.4 & 168.7 & 0.81 \\
1997 & 141.8 & 179.4 & 0.79 \\
\hline
\end{tabular}

Source: The Economic Report of the President, 1999 and 1991.

${ }^{*} \mathrm{CPIC}=$ consumer price index of all commodities.

${ }^{* *}$ CPIS $=$ consumer price index of all services.

The starting value of $p=$ CPIC/CPIS is in 1950. From a peak of 1.72 in 1950, the price ratio dropped to 1.21 in 1975 and then to a low of 0.79 in 1997. In the first period, the drop was 30 percent over 25 years, or an annual average of 1.2 percent; but after 1975, the drop is 35 percent over 22 years, or a staggering average rate of 1.59 percent.

In other words, so long as the economy remained basically closed, as until the late 1960s when the trade/GDP ratio centred around 10 percent, the manufacturing terms of trade fell because of the faster technical advance in $M$, but the fall was not sharp enough to actually lower the marginal value product of labour in M. Most likely, $p M P L m$ was then unchanged relative to $M P L s$, so that $M$ employment share stayed nearly unchanged between 1950 and 1970. But from 1975 on, $p$ fell so sharply that $p M P L m$ dropped relative to $M P L s$, so that $M$ 's employment share began a fast and steady fall.

Note that sector $S$ in our model combines the production of services with agriculture. Even though the agricultural share of labour fell during the twentieth century, the employment share of $S$ as a whole started to rise after 1970. Today, farming employs only 4 percent of the labour force, and manufacturing around 15 percent. To sum up, the technical change has been a constant presence in American life, but its impact on resource allocation can be quite different in a closed versus an open economy. Two things determine such allocation, namely relative prices and factors affecting the marginal labour productivities. 


\section{Real Wages}

Our analysis presented above is directly relevant to real wages and income distribution in the economy. Anything that impacts the labour allocation also influences real earnings, which are described as follows:

$$
W m=M W m / P=p M P L m /(\alpha p+\beta)
$$

and

$$
W s=M W s / P=M P L s /(\alpha p+\beta),
$$

where $(\alpha P m+\beta P s)$ equal the general price level $(P)$, with $\alpha$ and $\beta$ being the two constant consumption weights, and $W i$ is the average real wage in the $i$ th sector, i.e. the average money wage $(M W)$ divided by $P$. With $M$ being the progressive sector, the denominator of both real wages falls as $p$ falls with technical improvements. In a closed economy, $p M P L m$ rises, so that the real wage in $M$ rises unambiguously. At the same time, labour moves from $S$ to $M$, so that MPLs also goes up in view of the property of the diminishing marginal product of labour. Clearly then the real wage goes up in $S$ as well. Thus in a closed economy real wages always keep up with rising productivity. This is because the progressive sector then always attracts labour from the other sector.

The same results follow in an open economy as well, so long as pMPLm goes up. Both real wages will still rise, although the magnitude of their change is likely to be different from the autarchic case. However, if pMPLm falls, then the real wage behaviour could be paradoxical. The real wage in $M$ could rise or fall, because both the denominator of the $W m$ equation go down. Similarly, the real wage in $S$ could also rise or fall, because MPLs is now subject to conflicting pulls. As labour moves into $S, M P L s$ tends to fall, but the initial technical change tends to raise MPLs. Therefore, the real wage in services could also rise or fall.

The final outcome will depend on the rate of technical advance in the two sectors as well as the extent of the fall in $p$, which in turn depends not only on domestic and foreign elasticities of import demand but also on the rate of technical improvement in foreign countries. It is well known that manufacturing productivity growth in America's trading partners, such as Japan and Germany, was very strong between 1950 and 1990 . However, so long as the United States had a low trade ratio, as until 1970, giant rates of foreign growth did not have much effect on the US relative price of manufactures. But with increasing globalization after 1970 came an acceleration in the fall in such relative price, and that generated the paradox of shrinking real earnings in the backdrop of a continued rise in national productivity in the United States. The real culprit then is not technology but the effect of technology combined with increasing globalization, which causes labour to move out of the progressive sector. 


\section{Male and Female Wages}

What we have explained so far is the possibility of a general fall in average US real wages in the wake of rising national productivity, but it is well known that even though both the averages may have declined, some components of these averages have risen unambiguously. Real wages of the highly skilled as well of some women have soared. How do we move from sectoral wages to individual wages and industries comprising the two sectors? The analysis developed above is also fruitful at the individual level.

On average, service wages have declined faster than those in manufacturing, but a few service industries such as finance, legal aid and healthcare pay some of the highest wages in the country. The industrial wage structure, just like the average wages, are subject to the same three factors analyzed above - the relative price of manufacturing $(p)$, labour movements across the two sectors and marginal factor productivities. Real wages in the service sector as a whole fall when $p$ falls enough to cause labour to move out of $M$ into $S$, so that MPLs actually falls in spite of changes in technology. But employees in some service industries are not affected by this increased labour competition. For such workers real wages rise not only because of their own improving technology but also because their purchasing power is further enhanced by the fall in relative manufacturing prices. So their earnings soar while other service industries such as restaurants, transportation, tourism and retailing face the full blast of labour competition from those migrating from the dwindling manufactures.

A similar argument applies to relatively prosperous industries within manufacturing. If $p$ falls sharply, the $M$ sector on the whole contracts relative to $S$, but those manufacturing industries, such as computers, where the United States has a comparative advantage relative to the world actually expand because of their superior productivity growth. They enjoy a growth in real earnings, even though on average the manufacturing real wage shrinks. The United States both exports and imports manufacturing products, but such exports are dwarfed by such imports. Therefore, the nation is a net importer of manufactures.

Female wages have also risen for similar reasons. Historically, men's earnings have exceeded those of women. But women's educational achievements and hence productivity have climbed sharply since the early 1970s, and so have their wages in both $M$ and $S$, even though female wages still lag behind the male counterpart. Female wage growth has been strong but it has yet to bring about parity with male wages. Apparently, female productivity growth in some areas was large enough to overcome any disadvantage arising from a falling $p$ or growing labour competition from the contracting industries in $M$.

\section{Conclusions}

The real-wage fall or stagnation observed in the US economy since 1973 is an unprecedented event and can be only explained by something unprecedented in history. The argument generally accepted by the orthodoxy is that skilled-labour biased changes in technology are to blame for the earnings slowdown. However, this type of technical change is not unprecedented in history, because the United States has experienced labour-saving technical progress ever since the early nineteenth century. What is 
unprecedented is the increasing globalization of the American economy since 1970, and we have demonstrated that new technology works differently in a closed versus an open economy. In an open economy, technical improvements may generate a fall in some or all types of real earnings, but not in a closed economy.

\section{References}

Abel, A. and B. Bernanke, 1995, Macroeconomics, Reading, MA: Addison-Wesley.

Batra, R., 1973, "Non-Traded Goods, Factor Market Imperfections, and the Gains from Trade", American Economic Review, 64, (September), 706-713.

Batra, R., 1992, “The Fallacy of Free Trade”, Review of International Economics, 1, (November), 19-31.

Batra, R., 1993, The Myth of Free Trade, New York: Macmillan.

Bound, J. and G. Johnson, 1992, "Changes in the Structure of Wages in the 1980s", American Economic Review, 82, (June), 371-392.

Cline, W., 1997, Trade and Income Distribution, Washington DC: Institute for International Economics.

Feenstra, R. and G. Hansen, 2001, "Global Sharing and Rising Inequality: A Survey of Trade and Wages", (June), mimeographed.

Feenstra, R., 2003, A Textbook on International Trade, Princeton: Princeton University Press.

Fite, G. and J. Reese, 1973, An Economic History of the United States, Boston: Houghton Mifflin.

Gordon, R., 1998, Macroeconomics, Reading, MA: Addison-Wesley.

Gottschalk, P., 1997, "Inequality, Income Growth, and Mobility: The Basic Facts," Journal of Economic Perspectives, 11, (Spring), 21-40.

Jones, R.W., 1971, "A Three Factor Model in Theory, Trade and History", in Jagdish Bhagwati, et al., eds., Trade, Balance of Payments and Growth: Essays in Honor of C. P. Kindleberger, Amsterdam, 3-21.

Kennedy, K., 1996, "Deconstructing Protectionism: Assessing the Case for a Protectionist Trade Policy", Case Western Reserve Journal of International Law, (Winter), 28.

Levy, F. and R. Murnane, 1992, "US Earnings and Earnings Inequality: A Review of Recent Trends and Proposed explanations," Journal of Economic Perspectives, 30, (September), 1331-1381.

Salvatore, D., 1998, International Economics, New York: MacMillan.

Thurow, L., 1992, Head to Head, New York: William Morrow.

Thurow, L., 1996, The Future of Capitalism, New York: William Morrow.

U.S. Council of Economic Advisers, The Economic Report of the President, 1991 and 1999, Washington DC: Department of Commerce.

Williamson, G., 1991, "Productivity and American Leadership," Journal of Economic Literature, (March), 51.

Wood, A., 1995, "How Trade Hurt Unskilled Workers," Journal of Economic Perspectives, 9, (Summer), 57-80. 